\title{
CAN FOREIGN INVESTMENT IN REAL ESTATE IMPROVES HOST COUNTRY'S AFFORDABILITY?
}

\author{
Tajul Ariffin Masron* and Ema Izati Zull Kepili \\ School of Management, Universiti Sains Malaysia, \\ 11800 USM Pulau Pinang, Malaysia \\ *Corresponding author: tams@usm.my
}

\begin{abstract}
Inflows of foreign capital are necessary to complement the available domestic fund or capital of host countries. Foreign capital may also bring in management skills, latest technology and so on, which later has the potential to be transferred to local firms in host countries. It is expected that foreign capital will elevate host country's affordability. Nonetheless, this argument is very much one-way. Foreign capital is also expected to be able to exert negative consequences such as fuelling up domestic price (either stock market price, and/or real estate price) and failure to effectively transferring knowledge, skills and technologies, leading to unchanged or lower country's affordability level. Hence, this study aims at investigating the effect of foreign investment in real estate (FIRE) on host country's affordability. Using 30 emerging markets as a case for the period of 2000-2011, estimated by using fixed-effect model and complemented by 2-stage least square (2SLS) method, this study found that FIRE has a tendency to generate positive effect on countries' affordability. On the policy implication side, government can continue attracting foreign investment in real estate but it should be done cautiously as the effect is not elastic.
\end{abstract}

Keywords: Foreign investment, real estate, affordability, emerging markets

Published date: 21 April 2017

To cite this article: Masron, T. A., \& Ema Izati, Z. K. (2016). Can foreign investment in real estate improves host country's affordability? Asian Academy of Management Journal of Accounting and Finance, 12(2), 1-21. https://doi.org/10.21315/aamjaf2016.12.2.1

To link to this article: https://doi.org/10.21315/aamjaf2016.12.2.1 


\section{INTRODUCTION}

The inflows of foreign capital can be in various forms such as foreign direct investment (FDI), foreign portfolio investment (FPI) and foreign aids (AID). Abundant literatures have recognised the importance of FDI such as; (i) to provide a long-term capital which is normally missing in the target country yet suitable for economic development, (ii) to bring new technologies that are usually not available in the target country and expected to create spill-over (and subsequently crowding-in) effects as the new technologies usually spread beyond the foreign corporations, and (iii) to improve the business environment of the target country by introducing ethical business or rules of conduct. Errunza (2001) could be among the first to study the impact of FPI on economic development and concluded that resource mobilisation, contagion and volatility are unwarranted provided some preconditions for capital market openings and liberalisation sequencing are fully abide. The impact of AID could be a bit controversial as it requires us to distinguish between the effects of different kinds of aid, or else, the standard aid-growth regression may lead to erroneous conclusions due to this strategic bias problem (Minoiu \& Reddy, 2009). Among the most growing foreign capitals across the globe is foreign capital in services and one of them is foreign investment in real estate (FIRE). Unlike other types of foreign capital, FIRE is the most difficult form of foreign capital to be disentangled into short and long-term or into FDI or FPI. This point has been highlighted by Jiang, Chen and Isaac (1998), Sirmans and Worzala (2003) and He, Wang and Cheng (2011), who argued that although foreign investment in real estate is fully in the form of FDI, the objective remains the same - to earn higher returns to unit capital. ${ }^{1}$ Hence, its impact on economic development of a host county vis-à-vis affordability level is ambiguous.

On other development, a declining affordability level in most developed countries is getting serious consideration by policy makers. In the case of developed countries, Bramley (1994) in the UK, Stapledon (2010) and Wood and Ong (2011) for Australia, Wright and Hogue (2012) for Canada, and Bernanke (2009) and Holt (2009) for the US, have highlighted the incident of price bubble to take place, which later on reduced the housing affordability level. According to Trimbath and Montoya (2002), affordability ${ }^{2}$ is a public policy measure that has threedimensional space measured by home prices, household income and mortgage interest rates. Although in some countries the concern is about price bubble and bursts phenomenon, identifying the factors determining the price bubble is equally important, for instance, Agnello and Schuknecht (2009) has shown that in many developed countries, house price boom is always followed by price burst. In addition, it is interesting to note that there was a longer persistence period of burst than the boom period ${ }^{3}$ (see Table 1). 
Table 1

Period of boom and burst for selected developed countries

\begin{tabular}{clcc}
\hline & Country & Boom period & Burst period \\
\hline 1 & UK & $1983-1989(7)$ & $1990-1996(7)$ \\
2 & Japan & $1986-1991(6)$ & $1992-2006(15)$ \\
3 & Switzerland & $1983-1989(7)$ & $1990-1999(10)$ \\
4 & Denmark & $1983-1986(4)$ & $1987-1993(10)$ \\
5 & Finland & $1987-1989(3)$ & $1990-1993(4)$ \\
6 & Italy & $1987-1992(6)$ & $1993-1998(6)$ \\
7 & Spain & $1986-1991(6)$ & $1992-1998(7)$ \\
\hline
\end{tabular}

Note: Figure in ( ) denotes persistence level in years.

Source: Extracted and modified from Agnello and Schuknecht (2009, Table 2, p. 19).

Although several studies highlighted the recent trend of price reduction such as Klyuev (2008) and Holt (2009), the issue is whether it is a simple cycle of price drop following price increase or it reflects a more severe price fluctuation of boom and burst. The price boom and price burst could be reflecting a significant drop in economic activities and later on translated into significantly low gross domestic product (GDP). The Organisation for Economic Co-operation and Development [OECD] (2010) supported this negative implication of house price burst by stating that the extreme developments in housing markets were a key feature of the current economic crisis and the run up to it. Of the same view, André (2010) argued that in many OECD countries, the general increase in real house prices since the mid-1980s came to an abrupt halt immediately before the crisis began. As a result, large corrections in house prices in many countries reduced households' wealth and consumption, as well as residential investment.

The experience of developed countries with regards to house price visà-vis affordability may offer a good lesson to countries with emerging real estate markets. In particular, the point of concern is how to have reasonable house price in order to maintain country's affordability level. This issue is particularly interesting to research on as investors are looking for suitable location or real estate to invest in. According to Bernanke (2009), the net inflow of foreign saving to the US has increased from about $1.5 \%$ of GDP in 1995 to about $6 \%$ in 2006. Mortgage interest rates were falling despite the low savings rate in the US due to the influx of saving entering the US from other countries. Most of this saving came from countries with high savings rates such as Japan and the UK and from countries with rapidly growing economies such as China, Brazil, and the major oil exporting countries (Holt, 2009). With regard to house price, foreign investments may contribute 
to house price increase or if the existing price level is already high, they could contribute to price bubble or boom. Naturally, price increase by itself reflects profitability to investors and therefore, they will flow into economies with high price level by expecting the price level will continue to increase. Mihaljek (2005) highlighted this concern in several European Union countries such as Cyprus, the Czech Republic, Hungary and Slovakia. These countries have asked for a longer transitional period before they could allow for foreign investment in their real estate sector. This is due to the expectation that the impact of large-scale real estate purchases by foreign residents might cause the price to hike and the affordability to drop significantly. This issue has been highlighted by Glindro, Subhanij, Szeto and Zhu (2008) from policy implication perspective based on cyclical and bubble components of house price overvaluation. Overvaluation due to cyclical movements related to market frictions shall be mitigated if policy makers focus on strategy to reduce the magnitude and frequency of house price cycles. Among the suggested policies are such as loosening land use regulation, improving information availability (or market transparency) and strengthen property right protection. On the other hand, to counter the issue of bubble, which could be caused by market or investors' over-confidence in the housing market, the mitigating measures could include designing policies targeting at reducing investors' positive expectation on capital gains.

Moving on to the experience of several countries with emerging real estate market as shown in Table 2, countries like Austria, Bosnia, China, the Philippines and Thailand are unlikely to have a problem with house price movement as the growth rates are moderately positive. Other than these countries, they had at least once suffered from double digit growth in house price. Turkey has the most serious problem on house price, as the growth rates are persistently positive throughout the period under this study.

Nonetheless, according to OECD (2011), the experience of Austria requires a serious attention as it has been classified under the "moderate to large increase $(20 \%-90 \%)$ " group for the period between mid-1980s to 2008. The case of China too needs a serious attention although the figure revealed in Table 2 could be the overall house price index thus did not reflect the critical issue of house price in this country. Equally surprising is the case of huge drop in house price in Kazakhstan between 2001 and 2002. Unfortunately, not much can be discussed due to limited information and past study on Kazakhstan which surely warrant urgent research to be undertaken. The U-shaped growth pattern in the case of Romania, inverted U-shaped pattern in the case of Vietnam and upward trending growth pattern in the case of Lithuania suggest that investigating the factors pushing the pattern is very crucial. 
Table 2

House price and GDP growth rates in the selected emerging real estate market (in \%)

\begin{tabular}{cccccccc}
\hline & Austria & Bosnia & Bulgaria & China & Kazakhstan & Latvia & Lithuania \\
\hline 2001 & $3[0.86]$ & $6[4.40]$ & $9[4.20]$ & $3[8.30]$ & $-22[13.50]$ & $2[8.04]$ & $-1[6.74]$ \\
2002 & $1[1.69]$ & $-2[5.30]$ & $0[4.70]$ & $1[9.10]$ & $-6[9.80]$ & $5[6.47]$ & $-3[6.86]$ \\
2003 & $2[0.87]$ & $-1[4.00]$ & $3[5.50]$ & $3[10.00]$ & $3[9.30]$ & $3[7.20]$ & $6[10.25]$ \\
2004 & $3[0.87]$ & $0[6.10]$ & $4[6.70]$ & $6[10.10]$ & $12[9.60]$ & $8[8.68]$ & $3[7.35]$ \\
2005 & $5[2.59]$ & $4[5.00]$ & $6[6.40]$ & $3[11.30]$ & $5[9.70]$ & $10[10.60]$ & $6[7.80]$ \\
2006 & $3[2.40]$ & $2[6.20]$ & $5[6.50]$ & $2[12.70]$ & $2[10.70]$ & $12[12.23]$ & $7[7.84]$ \\
2007 & $4[3.67]$ & $-4[6.84]$ & $5[6.40]$ & $3[14.20]$ & $5[8.90]$ & $3[9.98]$ & $21[9.84]$ \\
2008 & $1[3.71]$ & $4[5.42]$ & $11[6.20]$ & $2[9.60]$ & $4[3.30]$ & $46[-4.24]$ & $12[2.93]$ \\
\hline & Mexico & Philippines & Romania & Thailand & Tunisia & Turkey & Vietnam \\
\hline 2001 & $4[-0.16]$ & $2[2.89]$ & $32[5.70]$ & $2[2.17]$ & $3[4.91]$ & $53[-5.70]$ & $0[6.89]$ \\
2002 & $5[0.83]$ & $4[3.65]$ & $22[5.10]$ & $2[5.32]$ & $1[1.80]$ & $35[6.16]$ & $3[7.08]$ \\
2003 & $15[1.35]$ & $2[4.97]$ & $17[5.20]$ & $1[7.14]$ & $5[5.55]$ & $24[5.27]$ & $3[7.34]$ \\
2004 & $8[4.05]$ & $4[6.70]$ & $12[8.40]$ & $0[6.34]$ & $6[6.11]$ & $17[9.36]$ & $8[7.79]$ \\
2005 & $9[3.21]$ & $5[4.78]$ & $5[4.17]$ & $3[4.60]$ & $11[4.02]$ & $16[8.40]$ & $8[8.44]$ \\
2006 & $7[5.15]$ & $3[5.24]$ & $3[7.90]$ & $3[5.09]$ & $3[5.35]$ & $17[6.89]$ & $6[8.23]$ \\
2007 & $4[3.26]$ & $3[6.62]$ & $7[6.00]$ & $2[5.04]$ & $5[6.34]$ & $15[4.67]$ & $6[8.46]$ \\
2008 & $7[1.19]$ & $3[4.15]$ & $10[7.93]$ & $2[2.48]$ & $5[4.62]$ & $14[0.66]$ & $5[6.31]$ \\
\hline
\end{tabular}

Note: Figure in [ ] stands for GDP growth rate.

Source: OECD Statistics and various countries' Department of Statistics.

The next question that everyone would ask is whether house price increase will immediately lower a country's affordability? The answer is not straightforward. It depends very much on the level of income generated. It is generally believed that as long as income growth is higher than the house price growth, affordability will improve, and vice versa. As demonstrated in Table 2, it is difficult to conclude that affordability is getting better or worse over the year except for few countries such as Austria, Mexico and Turkey for apparent drop in affordability level and China for enjoying improving affordability level. While there are various possible explanations for house price increase (or drop) as well as improvement (or declining) income level in each country, what is common to both is the role of foreign capital inflows. Hence, this study attempts to investigate the role played by foreign capital on affordability level. This issue can be considered among the first as far as emerging real estate markets are concerned and therefore, by itself a contribution to the literature. 


\section{LITERATURE REVIEW}

\section{Determinants of Affordability}

Income is generally believed as the primary positive determinant of house affordability. Surprisingly, Girouard, Kennedy, van de Noord and André (2006) found that from 2001 onwards, the deceleration of disposable income in the US which was partly due to series of recessions, has been accompanied by a sharp acceleration of real house prices. Finicelli (2007) concurred this finding by showing a strong correlation between real house prices and per-capita disposable income in the US. Since 1975, the two are moving in the different direction. For instance, for the period from 1975 to mid-1984 and 2003 onwards, disposable income is lower than house prices but between mid-1984 and 2003, house prices tend to be larger than disposable income. The scenario in South Korea as discussed in Kim and Cho (2010) revealed that rather than income per se, future income expectation is more powerful in determining house price behaviour. In the wake of the 1997 economic crisis, when the scenario is very gloomy and prospect of economic recovery is difficult, people started to be very concern about their future employment and income. Although lower demand has helped to bring the house prices into a more stable level, but this low demand has also an implication on supply of house. The accumulated effect of the decrease in housing production in the aftermath of the Asian crisis has led housing prices to substantially rise in the late 2001, especially in the Seoul Capital Region. In summary, this study believed that income expectation rather than income per se as crucial determinant of house affordability. Hence, it is generally hypothesised that income expectation as having a negative effect on house affordability.

Instead of claiming the role of income or income expectation, Finicelli (2007), upon observing a counter cyclical movement between house prices and disposable income in the US, has plotted the data for real mortgage interest rates. Finicelli (2007) concluded that the dramatic rise in interest rates could partly account for the housing market weakness in the first half of the 1980s. Similarly in the case of South Korea, following the privatisation of government-owned Korea Housing Bank in 1997, commercial banks are now allowed to offer mortgage loans (Kim \& Cho, 2010). Combined with low demand due to an anticipation of employment and income uncertainty and thus, housing price collapsed in 1998, low interest rate was believed as one of the solutions to lure more consumers to buy house. As a result, following economic recovery after the serious setback of the 1997 economic crisis, a record low of interest rates vis-à-vis rapid expansion of consumer credit has triggered house prices upward once again. As part of government efforts to combat this issue, as far as interest rates and loans are concerned, by restricting mortgage 
lending especially in the areas of 'hot' market or in the areas where the level of house price can shot down the affordability. Hot market mainly refers to big cities such as Seoul. With conjunction with interest rates, the strong relationship can be a reflection of that housing is used as collateral in mortgage lending and that house price movements affect the borrowing capacity of households and firms. There is also evidence that credit often leads house prices, consistent with the findings of Mendoza and Terrones (2008). Although European Central Bank (2003) reminded about potentially difficult to gauge the relationship between mortgage debt and house prices, partly due to interference of factors such as interest rates and expected future income, there are still some studies which able to demonstrate the association between the two variables such as Borio and McGuire (2004). In short, based on the available literature, this study hypothesised that interest rates (IR) and credit lending, as having implication on house affordability ${ }^{4}$

On another note, studies by OECD (2004) for Netherlands, OECD (2005a, 2005b) in the case of UK and South Korea, and OECD (2006) for Ireland concluded that land restriction, combined with complex and inefficient local zoning regulations and slow authorisation process, is among crucial factors for rigidity of housing supply or low level of new housing construction, leading to limited new housing supply and subsequently rising house prices. Similarly, English (2013) argued that to build a house in New Zealand is very costly and to make thing worse it takes too long to build a house. This is because land is being reserved exclusively for development, making transforming the areas for housing tremendously difficult. Borrowing economic term to reflect this phenomenon, the land vis-à-vis house supply is totally irresponsive to any change in demand for house. Although it is very straightforward to think about house price to move upward owing to supply gap or shortage, the inelastic supply remained. Similar to OECD (2005b), Kim and Cho (2010) also observed similar reason of rising house price prior to 1988 in South Korea. The accumulated pressure from demand for house on the housing market has been cited by Kim and Cho (2010) as the primary driver. Unlike in the case of New Zealand, in which no clear proactive measure or response is taken to overcome the issue, Korean government responded well and capable to improve the housing conditions by introducing a radical policy of increasing the supply of houses by another two million in 1992. Throughout 1990 s, housing prices remained stable and the issue of affordability has almost disappeared. House price issue reappeared in the 2000s but this time around, the source of problem is due to insufficient house supply. Although Kim and Cho (2010) did not directly link this issue with the activities of wealthy Korean in buying more than one house, we believe this could be another strong reason as according to Kim and Cho (2010) the ratio between dwellings and households does not show housing shortage as really an issue at that particular time. Girouard 
et al. (2006) also revealed the same consideration with a slight different objective namely buy-to-let. This buy-to-let market has grown substantially over the past several years in the countries for which data are available. United States, United Kingdom, Australia and Ireland are among the examples. Buy-to-let strategy is partly supported by low interest rates. Lower interest rates have increased the return on rental property for investors, enhancing the attractiveness of, and demand for, housing as an investment. Buy-to-let activities actually help to push the price upwards as it absorbed house availability in the market quickly, leaving the market with likely insufficient supply of houses. Daly (2010), in particular offers a unique discussion on why affordability in Australia is dropping significantly and unlikely to fall in the near future. In explaining why Australia has three out of five most unaffordable housing markets in the world, Daly (2010) found that the insufficient supply of house to cover huge demand for house has led to house price bubble with not prospect to burst soon. In the nutshell, this study postulated that house supply gap matters and has strong negative implication on house affordability.

Finally, as point of concern and rarely discussed is regarding the role of foreign capital. According to $\mathrm{He}$ et al. (2011), among the important factor that drives the influx of foreign direct investment in China's real estate development are the rapid house prices, which accompanied the rapid economic growth. With diverse economic development across China, provinces with higher housing prices will automatically able to lure real estate FDI into their areas. Since the focus of this study is on the determinants of FDI in China's real estate development, whether or not this inflow contributes to accelerated house price or house affordability is not properly discussed. Nevertheless, it is expected that the inflows will exacerbate the existing house price level. In similar note to He et al. (2011), Bernanke (2009) emphasised the inflow of foreign saving into the US economy, especially to the US mortgage market, has helped to certain extent the rise in house prices and lower the house affordability. Masron and Mohd Nor (2016) has used channel approach to investigate the implication of foreign investment in real estate in several countries with emerging real estate market. General result shows that the effect of foreign capital on house price is larger than its effect on real income, implying the negative effect of foreign capital on host countries' affordability. Unfortunately, this result is based on the assumption that house affordability is seen from price-income ratio perspective, which is only partially reflecting the full picture of house affordability. Therefore, this study hypothesised that foreign capital affect house affordability negatively.

In addition to the above-mentioned factors, some studies suggested other unique determinants. For instance, Bentzien, Rottke and Zietz (2012), in investigating the issue of affordability of home ownership in Germany, found that 
the removal of homeowner subsidies in 2005 is likely the primary explanation to lower or dropping house affordability. Another interesting determinant is suggested by English (2013). He highlighted the issue of non-standard way of constructing items related to housing such as window, which is largely explained by the unique industry regulation which favours single person operations. This has resulted in a stagnated of industry's productivity in the past 30 years and worryingly fall under the pre-1978 level. Unfortunately, due to difficulty in finding the timing and application of homeowner subsidies as well as industry regulation in all countries under consideration, these factors are left for future research.

\section{Affordability Measurement}

Several indicators have been used to indicate the level of house affordability such as price to income ratio (PIR), deposit to income ratio (DIR) and cost of mortgage to income ratio (MIR). The three dimensions carry their own meaning and importance. They may not be perfectly matching to each other but complementary measures. Hence, it is vital to have three of them in the analysis to find a robust conclusion. The first measurement is the most straightforward indicator. Increasing PIR means affordability vis-à-vis welfare of public is falling. This is because higher portion of income is now has to be channelled for obtaining a house. Therefore, Bentzien et al. (2012) argued that from a social policy perspective, high PIR implies that low-income households will be left with insufficient or may be nothing to cover their non-housing needs such as foods, clothing and education. The second DIR is another crucial indicator of affordability, owing to the theory of "wealth" and "income constraint" developed by Jackson and Kaserman (1980) and "income constraint" term introduced by Pattison, Diacon and Vine (2010). It reflects the ability of households to qualify for bank's financing. Very often, banks or any financial institutions will require households to demonstrate the ability to repay the debt by having sufficient savings or other assets which later on can be used as collateral or to cover the down-payment on the loan. Those savings will also be needed to finance implicit cost of transaction associated with the purchase of house such as taxes, legal and agent fees (Bentzien et al., 2012). Finally, income constraint concept by Pattison et al. (2010) can also be extended to discuss the importance of MIR. Summarised succinctly by Bentzien et al. (2012), MIR could be a good indicator of affordability as it represents the constraint in income due to the responsibility, not limited to include recurring expenses of the house such as tax payment, maintaining and repairing cost but more importantly, to serve principal and interest on the mortgage. In summary, the three represents a threshold in deciding the affordability level, for the government to offer its financial support and for the bank to choose the appropriate or prospective borrowers. For instance, in many developed countries, the threshold of affordability is set at one-third of 
disposable household income. In other words, if the financial burden exceeds onethird of income, those households are no longer considered as within bearable state $^{5}$

Daly (2010), by using different names has defined or divided affordability concept into three possible angles, namely income affordability, purchase affordability, and repayment affordability. Income affordability is in essence similar to PIR, purchase affordability can be corresponding to DIR, and repayment affordability can be analogous to MIR. The importance of using various measurements to capture the fullest possible aspect of affordability is being stressed by Girouard et al. (2006). According to Girouard et al. (2006), PIR could be insufficient metric to evaluate housing affordability especially when Girouard et al. (2006) confirmed that house prices do not appear to have strong association with income by a stable long-run relationship due to ever changing cost of mortgage time to time.

Finally, National Association of Realtors (NAR) has come out with house affordability index (HAI). High HAI implies that this family is more able to afford the median priced home. The underlying idea is quiet similar to DIR except that in this measurement, median income value has been added as a benchmark. It means an index value of 100 refers to a family with the median income that has exactly enough income to qualify for a mortgage on a median-priced home. An index above 100 signifies that family earning the median income has more than enough income to qualify for a mortgage loan on a median-priced home, assuming a $20 \%$ down payment. Unfortunately, despite its well acceptability, the information on median income level is not available for all countries under study. Hence, we reserve this measurement for future research.

\section{METHODOLOGY}

Taking into account view from past studies, this study observed that the house affordability model could be specified as follows:

$$
\text { AFFORD }_{i, t}=\beta_{0}+\beta_{1} \text { FIRE }_{i, t}+\beta_{2} \operatorname{INCOME}_{i, t}+\beta_{3} I R_{i, t}+\beta_{4} \operatorname{SSGAP}_{i, t}+\varepsilon_{i, t}
$$

where $A F F O R D$ represents house affordability, FIRE stands for foreign investment in real estate, INCOME denotes household income, $I R$ represents interest rates, and SSGAP stands for house supply gap. All variables enter in logarithmic form. Nonetheless, the effect of FIRE on AFFORD can be misleading if this study does not control for other forms of foreign capital. This is particularly true in the case of FDI in manufacturing as proven to be income- (or growth-enhancing) by many 
past studies. Hence, we add $F D I$ in other sectors $(F D I)$ to control for the potentially biased effect of FIRE on $A F F O R D$. Incorporating additional FDI into account and after transforming all variables into log form, Equation (1) will become:

$$
\begin{aligned}
\ln \operatorname{AFFORD}_{i, t}= & \beta_{0}+\beta_{1} \ln F I R E_{i, t}+\beta_{2} \ln I N C O M E_{i, t}+\beta_{3} \ln I R_{i, t} \\
& +\beta_{4} \ln \operatorname{SSGAP}_{i, t}+\beta_{5} F D I_{i, t}+\varepsilon_{i, t}
\end{aligned}
$$

where $\ln$ stands for log. As discussed in the literature section, the use of all three proxies for house affordability is the most preferred option. Unfortunately, due to data unavailability for mortgage in some countries under study, this study only utilises PIR and DIR as proxies for house affordability. Deposit is later on proxied by saving ${ }^{6}$ Although DIR stands for domestic over income ratio, in this study we prefer to use price-deposits ratio (PDR). This is to ensure that the index is having similar feature with PIR. FIRE is represented by total foreign investment in real estate, INCOME is proxied by GDP per capita in a lagged period and $I R$ is represented by long-term lending rates. This study uses lagged 1-period of INCOME for two reasons: (i) current consumption is very much depending on last period income level, and (ii) to avoid high multicollinearity with the dependent variable. The most difficult part is on the measurement of SSGSP in the absent of actual data on house supply gap. Ideally, one should measure the level of optimum level of house supply (OHS) by dividing the total value of house constructions (CONS) with optimum level of house price (OHP) which can bring in one-to-one ratio of house ownership. It means that at that price level of house, every citizen can afford to buy one. As all countries in this study are not homogenous in many aspects, the level of OHS, CONS and OHP will also be dissimilar. As no information available to calculate all the indicators, at this stage, this study assumes that all countries have similar level of OHS and set it as 1. Then, this study relies on CONS as a ratio of GDP to represent current level of supply. Deducting 1 (optimum OHS) with CONS/GDP will generate an indicator, which is used in this study to mirror the possible level of house supply gap. Of course, this measurement is not the most perfect one but measurable for the time being. Future study can critically identify the more appropriate proxy or measurement for house supply gap. FDI in other sector or FDI, will be measured by total FDI minus FIRE. Originally, this study wishes to focus on FDI in manufacturing sector as the most suitable candidate to be a control variable by expecting that FDI in manufacturing could be the most influential factor that brings the affordability level upwards. This intuition is in line with bulk of studies on the implication of FDI in general on GDP of host countries in which FDI is found to have a tendency to generate positive impact on host countries' income. Although it seems that the use of FDI in other sectors could be misleading, considering that FDI in manufacturing is the dominant component in total FDI, using FDI in other sectors may not be creating bias in the result. In summary, the list of measurements and source of data are shown in Table 3. 
This study employs selected countries with emerging real estate market due to mainly data limitation. Hence, this study only utilises annual data for 30 countries for the period from 2000 to 2011. The countries are Austria, BosniaHerzegovina, Bulgaria, China, Kazakhstan, Latvia, Lithuania, Mexico, the Philippines, Romania, Thailand, Tunisia, Turkey, Vietnam, Republic Czech, Estonia, Hungary, Slovakia, South Korea, Serbia, Taiwan, Costa Rica, Croatia, Cyprus, Macedonia, Malaysia, Myanmar, Indonesia, Brunei and Lebanon.

Table 3

Measurements and sources of variables

\begin{tabular}{|c|c|c|c|}
\hline No. & Variable & Measurement & Source \\
\hline 1 & $\begin{array}{l}\text { AFFORD } \\
\text { PIR }\end{array}$ & House Price/Income per capita & $\begin{array}{l}\text { Own calculation } \\
\text { House Price: OECD Statistics and } \\
\text { Country's Department of Statistics }\end{array}$ \\
\hline & PDR & $\begin{array}{l}\text { House Price/Domestic Savings } \\
\text { per capita }\end{array}$ & Income and Savings: World Bank (2013) \\
\hline 2 & FIRE & $\begin{array}{l}\text { Foreign investment in real } \\
\text { estate (as ratio of GDP) }\end{array}$ & $\begin{array}{l}\text { OECD Statistics and Country's } \\
\text { Department of Statistics }\end{array}$ \\
\hline 3 & INCOME & Real GDP per capita & World Bank (2013) \\
\hline 4 & IR & Interest rates on lending & Global Market Information Database \\
\hline 5 & SSGAP & $1-(\mathrm{CONS} / \mathrm{GDP})$ & CONS: World Bank (2013) \\
\hline 6 & FDI & FDI - FIRE (as ratio of GDP) & FDI: UNCTAD (2013) \\
\hline
\end{tabular}

On the estimation procedure, considering the limited information that this study could gather, panel data approach is the option to go. Given the limited time frame, this study examines the model by using static panel data analysis. Initially, this study lets the model without any control variable to be estimated. Later on, more control variables are added to take into accounts the period specific characteristics and country's specific characteristics. In order to minimise the risk of being biased and inefficient in the presence of endogeneity issue, this study does analyse the model by using 2-Stage Least Square (2SLS). EVIEWs is used to estimate the equation.

\section{RESULTS AND DISCUSSION}

We start the analysis by looking at the simple correlation analysis as shown in Table 4. Some interesting points are worthy to be mentioned here. The negative correlations between FDI and PIR and PDR are in line with the general believe that FDI is growth- or income-enhancing and hence, should be affordability-improving 
factor although the level of association is relatively poor. However, the highest positive correlation between FDI and lagged INCOME provides preliminary weak support on the important role of economic development of host country in attracting FDI inflows. The correlation between two proxies of affordability is as expected. The high but imperfect correlation justifies the complementarities role by the two variables. Positive link between SSGAP and FIRE also implies the possible complementing role of FIRE in offering infrastructure to local suppliers. The plausible implication of this contribution of FIRE could be seen from the positive association between FIRE and INCOME. Overall, none high correlation is observed and therefore, will not pose any serious threat of endogeneity problem. Regarding the contradicting correlation between FIRE-PIR and FIRE-PDR could due to the fact that FIRE helps in improving income level but that high income earned is not translated into high saving, leading to potentially lower affordability. The detail about the reasons for the later is for future study and beyond the scope of this study.

Table 4

Correlation analysis

\begin{tabular}{|c|c|c|c|c|c|c|}
\hline & \multicolumn{2}{|c|}{ lnAFFORD } & \multirow{2}{*}{ lnFIRE } & \multirow{2}{*}{$\operatorname{lnINCOME}(-1)$} & \multirow{2}{*}{$\ln I R$} & \multirow{2}{*}{$\operatorname{lnSSGAP}$} \\
\hline & $\ln P I R$ & $\operatorname{lnPDR}$ & & & & \\
\hline $\ln P D R$ & 0.9069 & 1.0000 & & & & \\
\hline $\operatorname{lnFIRE}$ & -0.3333 & 0.3654 & 1.0000 & & & \\
\hline $\operatorname{lnINCOME}(-1)$ & 0.0442 & -0.1964 & 0.3200 & 1.0000 & & \\
\hline $\ln I R$ & -0.3031 & 0.3233 & 0.1992 & -0.2464 & 1.0000 & \\
\hline $\operatorname{lnSSGAP}$ & 0.2538 & -0.3322 & 0.2080 & 0.2578 & -0.1160 & 1.0000 \\
\hline $\operatorname{lnFDI}$ & -0.0702 & -0.0403 & -0.3187 & 0.4173 & -0.1510 & -0.1662 \\
\hline
\end{tabular}

Table 5 presents the results of the first AFFORD model which employs PIR as dependent variable. The analysis started by pooling the data and running with the assumption that all countries are homogeneous. In the next stage, the model has been controlled by country specific effect (or country-fixed effect) ${ }^{7}$ and in addition, the third model is being controlled for regional effect with the assumption that those countries which belong to the same region are homogeneous. Comparing pooled, country-fixed and region-fixed models, the third model seems to outperform pooled based on several criteria such as higher adjusted-R2 and lower standard error of regression. Nonetheless, country-fixed model tends to be better than the third model with overwhelmingly high adjusted-R2. Finally, the forth model of country-random effect, which is the best in its group, is run and compared with the country-fixed effect model. In doing so, Hausman test is employed and the result 
shows that fixed-effect model is superior to random-effect model. 2SLS is still introduced to minimise the risk of bias due to endogeneity problem although from correlation analysis, no serious threat is expected.

Table 5

Regression results [Dependent Variable: InPIR]

\begin{tabular}{|c|c|c|c|c|c|}
\hline & Pooled & Country-fixed & Region-fixed & Country-random & 2SLS \\
\hline Constant & $\begin{array}{c}1.14 \\
{[-0.46]}\end{array}$ & $\begin{array}{c}-0.63 * * * \\
{[-3.04]}\end{array}$ & $\begin{array}{c}5.16 \\
{[0.44]}\end{array}$ & $\begin{array}{c}0.11 \\
{[0.16]}\end{array}$ & $\begin{array}{c}1.04 \\
{[0.35]}\end{array}$ \\
\hline $\operatorname{lnFIRE}$ & $\begin{array}{c}-0.65 * * * \\
{[-4.38]}\end{array}$ & $\begin{array}{l}-0.04 * \\
{[-1.88]}\end{array}$ & $\begin{array}{c}-0.62 * * * \\
{[-3.75]}\end{array}$ & $\begin{array}{c}0.04 \\
{[1.46]}\end{array}$ & $\begin{array}{c}-0.08 * * * \\
{[-3.90]}\end{array}$ \\
\hline $\operatorname{lnINCOME(-1)}$ & $\begin{array}{c}-1.84 * * \\
{[-2.12]}\end{array}$ & $\begin{array}{c}-0.38 * * * \\
{[-6.39]}\end{array}$ & $\begin{array}{c}-2.60 \\
{[-0.48]}\end{array}$ & $\begin{array}{c}-0.48 * * * \\
{[-3.40]}\end{array}$ & $\begin{array}{l}-2.04 * \\
{[-1.71]}\end{array}$ \\
\hline $\ln I R$ & $\begin{array}{c}0.74 * * * \\
{[2.73]}\end{array}$ & $\begin{array}{l}0.05^{* * *} \\
{[12.85]}\end{array}$ & $\begin{array}{l}0.57 * \\
{[1.97]}\end{array}$ & $\begin{array}{c}0.04 \\
{[0.97]}\end{array}$ & $\begin{array}{c}1.09 * * * \\
{[3.25]}\end{array}$ \\
\hline $\operatorname{lnSSGAP}$ & $\begin{array}{c}0.47 \\
{[1.09]}\end{array}$ & $\begin{array}{c}0.16 \\
{[0.68]}\end{array}$ & $\begin{array}{c}0.84 * \\
{[1.75]}\end{array}$ & $\begin{array}{c}0.42 * * * \\
{[3.11]}\end{array}$ & $\begin{array}{c}0.53 \\
{[0.98]}\end{array}$ \\
\hline $\operatorname{lnFDI}$ & $\begin{array}{c}-0.12 \\
{[-1.20]}\end{array}$ & $\begin{array}{c}-0.02 \\
{[-0.22]}\end{array}$ & $\begin{array}{c}-0.11 \\
{[-1.11]}\end{array}$ & $\begin{array}{c}-0.07 * * * \\
{[-2.95]}\end{array}$ & $\begin{array}{c}-0.18 \\
{[-1.38]}\end{array}$ \\
\hline & \multicolumn{5}{|c|}{ Model Criteria } \\
\hline Adj- $R^{2}$ & 0.24 & 0.90 & 0.26 & 0.16 & 0.25 \\
\hline S.E. of Reg. & 1.41 & 0.13 & 1.38 & 0.15 & 1.41 \\
\hline $\begin{array}{l}\text { F-stat } \\
\text { (Overall) }\end{array}$ & $\begin{array}{c}8.74 * * * \\
(0.00)\end{array}$ & $\begin{array}{c}3072.12 * * * \\
\quad(0.00)\end{array}$ & $\begin{array}{c}6.43^{* * * *} \\
(0.00)\end{array}$ & $\begin{array}{c}8.36^{* * * *} \\
(0.00)\end{array}$ & $\begin{array}{c}10.79 * * * \\
(0.00)\end{array}$ \\
\hline $\begin{array}{l}\text { F-stat } \\
\text { (Redundant) }\end{array}$ & - & $\begin{array}{c}3157.16^{* * *} \\
\quad(0.00)\end{array}$ & $\begin{array}{l}2.16^{*} \\
(0.09)\end{array}$ & - & - \\
\hline Hausman-Test & - & - & - & $\begin{array}{c}3.52 \\
(0.06)\end{array}$ & - \\
\hline
\end{tabular}

Notes: $*, * *$ and $* * *$ denote significant at $10 \%, 5 \%$ and $1 \%$, respectively. Figure in [ ] stands for $t$-statistic and figure in ( ) represents $p$-value. S. E. of Reg. = Standard error of regression

The results of FIRE are consistently negative for all but insignificant in the case of country-random effect model, implying the robustness of the effect of FIRE on PIR. FIRE has a tendency to push the house affordability upward although the size of coefficient is relatively small. The result of FIRE on PIR after controlling for the potential endogeneity issue under the 2SLS approach offers similar result as country-fixed effect model although the size of the coefficients are slightly different. This result is consistent with the earlier finding by Masron and Mohd 
Nor (2016) who applied different approach in evaluating the effect of FIRE on AFFORD.

The significant negative effect of lagged INCOME on PIR, implies that the affordability-improving effect of income. The effect of INCOME can be interpreted in two ways. Firstly, the lagged INCOME could represent income in the past, which can be used to determine today's ability to buy a house. Meaning, if income level in high in the past, it has directly contributed to the level of today's ability to own a house. Secondly, it may represent people's expectation about the continuation of future income level. In other words, if people are optimistic that their income will continue to rise (or conversely down), automatically affordability will also be increasing (decreasing) by virtue of high expectation on future income. The effect of INCOME can also be expected to be much higher than normal if people are expecting that their INCOME will be consistently improving (or decreasing) for a longer period of time and this could be the explanation of high coefficient of INCOME on PIR under 2SLS approach.

The result of IR on PIR is also found to be positive and significant in all models, except country-random effect model. This result is in line with some previous studies as well as theoretical ground developed and discussed in literature review. Since IR is a cost to own a house, increasing IR surely lowers the affordability, a reflection to positive effect of IR on PIR. Hence, controlling IR is among crucial factors to maintain people affordability. Moving on to SSGAP, although it is suggested by previous studies that supply gap as among important determinants of house affordability, it is found insignificant in this study. One possible explanation is because of poor measurement of supply gap. However, the more surprising point is the insignificant impact of FDI on PIR when many studies have confirmed the positive role of FDI on economic development. Two possible explanations can be offered here. The first justification could be the poor proxy for FDI in manufacturing and the second justification could be because not all countries under study are receiving huge amount of FDI, with a special exception for China.

In the second model, as shown in Table 6, we use PDR as a proxy for AFFORD. While the overall story for model criteria is similar to PIR model, the results are a bit different. For instance, the effect of SSGAP in this model is found to be significantly influencing the level of AFFORD. The result under fixed-effect model, which is superior to the rest of static effect model, is comparable to 2SLS model although the size of the coefficient is slightly larger in the case of 2SLS, implying the lower the supply gap of housing, the higher the demand for deposit in getting the right to buy a house. Implicitly, it may signal two things. First, a higher 
deposit requirement may be an automatic implication of high price due to short of supply of house although in rates, they remain the same. Secondly, house suppliers demanded the house price increment and the level of demand for higher price will be stronger if the gap is very significant. Regarding why the SSGAP is only significant in the second model could probably because the ability to get sale and purchase $(\mathrm{S} \& \mathrm{P})$ is very much depending on the ability to pay the down payment, which reflected in the saving behaviour of the citizens in each country. In other words, people may have the ability to pay the monthly instalment but fail to get a house due to the failure to pay the deposit or down-payment which normally, as in the case of Malaysia, set to be around $10 \%$ of total selling price. On the result of FIRE, the results are consistent with the first model that FIRE is significantly strengthened positively the affordability level of host country.

Table 6

Regression results [Dependent Variable: $\ln P D R]$

\begin{tabular}{|c|c|c|c|c|c|}
\hline & Pooled & Country-Fixed & Region-Fixed & Country-Random & 2SLS \\
\hline Constant & $\begin{array}{c}7.61 * * * \\
{[2.95]}\end{array}$ & $\begin{array}{c}0.78 \\
{[1.43]}\end{array}$ & $\begin{array}{c}1.26 \\
{[0.54]}\end{array}$ & $\begin{array}{c}2.03 \\
{[1.13]}\end{array}$ & $\begin{array}{c}11.83^{* * * *} \\
{[3.61]}\end{array}$ \\
\hline $\operatorname{lnFIRE}$ & $\begin{array}{c}-0.66^{* * * *} \\
{[4.38]}\end{array}$ & $\begin{array}{l}-0.05^{*} \\
{[2.13]}\end{array}$ & $\begin{array}{c}-0.54 * * * \\
{[6.67]}\end{array}$ & $\begin{array}{c}0.10 \\
{[1.16]}\end{array}$ & $\begin{array}{c}-0.27 * * * \\
{[4.14]}\end{array}$ \\
\hline $\operatorname{lnINCOME}(-1)$ & $\begin{array}{c}-3.21^{* * *} \\
{[-3.55]}\end{array}$ & $\begin{array}{c}-0.54 * * * \\
{[-4.08]}\end{array}$ & $\begin{array}{c}-2.10^{* *} \\
{[-2.25]}\end{array}$ & $\begin{array}{c}-0.62 \\
{[-1.61]}\end{array}$ & $\begin{array}{c}-4.58 * * * \\
{[-3.22]}\end{array}$ \\
\hline $\ln I R$ & $\begin{array}{c}0.98^{* * *} \\
{[3.20]}\end{array}$ & $\begin{array}{c}0.06 \\
{[1.28]}\end{array}$ & $\begin{array}{c}1.03 * * * \\
{[7.09]}\end{array}$ & $\begin{array}{c}0.50 * * * \\
{[3.06]}\end{array}$ & $\begin{array}{c}0.77 \\
{[1.60]}\end{array}$ \\
\hline $\operatorname{lnSSGAP}$ & $\begin{array}{l}0.84^{*} \\
{[1.81]}\end{array}$ & $\begin{array}{l}0.31 * * \\
{[2.33]}\end{array}$ & $\begin{array}{c}0.06 \\
{[0.24]}\end{array}$ & $\begin{array}{c}1.01 * * * \\
{[2.70]}\end{array}$ & $\begin{array}{l}0.74 * \\
{[1.75]}\end{array}$ \\
\hline $\operatorname{lnFDI}$ & $\begin{array}{c}-0.17 \\
{[-1.61]}\end{array}$ & $\begin{array}{c}-0.06 * * * \\
{[-3.51]}\end{array}$ & $\begin{array}{c}-0.03 \\
{[-0.75]}\end{array}$ & $\begin{array}{c}-0.10 \\
{[-1.53]}\end{array}$ & $\begin{array}{c}-0.28 * * * \\
{[-4.87]}\end{array}$ \\
\hline & \multicolumn{5}{|c|}{ Model Criteria } \\
\hline Adj- $R^{2}$ & 0.34 & 0.92 & 0.75 & 0.24 & 0.35 \\
\hline S.E. of Reg. & 1.39 & 0.32 & 1.17 & 0.35 & 1.44 \\
\hline $\begin{array}{l}\text { F-stat } \\
\text { (Overall) }\end{array}$ & $\begin{array}{c}12.30 * * * \\
(0.00)\end{array}$ & $\begin{array}{c}586.12^{* * * *} \\
(0.00)\end{array}$ & $\begin{array}{c}38.57 * * * \\
(0.00)\end{array}$ & $\begin{array}{c}2.36 * * * \\
(0.00)\end{array}$ & $\begin{array}{c}11.18^{* * *} \\
(0.00)\end{array}$ \\
\hline $\begin{array}{l}\text { F-stat } \\
\text { (Redundant) }\end{array}$ & - & $\begin{array}{c}541.37 * * * \\
(0.00)\end{array}$ & $\begin{array}{c}7.01^{* * *} \\
(0.00)\end{array}$ & - & - \\
\hline Hausman-Test & - & - & - & $\begin{array}{c}1.50 \\
(0.08)\end{array}$ & - \\
\hline
\end{tabular}

Notes: $* * *$ and $* * *$ denote significant at $10 \%, 5 \%$ and $1 \%$, respectively. Figure in [ ] stands for $t$-statistic and figure in ( ) represents $p$-value. S. E. of Reg $=$ Standard error of regression. 
The results of this study demonstrate that FIRE in general is affordabilityenhancing. Hence, any country which wishes to have more FIRE to inflow should treat this inflow with cautious. Does it mean that we should entertain the inflow of FIRE? The answer is surely difficult to be confirmed. Comparing the primary source of affordability in both models may hint the possible answer. In the first model, if we compare the effect of IR and FIRE, in which both have a contradicting effect, we observe that the effects of IR in cross-fixed and 2SLS models tend to higher than FIRE. This implies that in order to improve country's affordability level, government should focuses more on reducing interest rates. In the second model, the discussion is more interesting. Although the impact of IR is no longer significant, there are now SSGAP and FDI (in other sectors) emerged as another crucial factors determining the level of affordability. On the positive note, FDI has a consistent result of income-improving and the size of coefficient is slightly higher than FIRE. This means that if we combine these two variables' effect, the overall effect on host countries is positive. Whether or not FIRE is suitable and what its connection with FDI, this study borrows results from Masron and Fereidouni (2012). Masron and Fereidouni (2012) in their study concluded that FDI and FIRE are cointegrated and inflows of FIRE might be bringing more FDI in other sectors as FIRE serves to provide more facilities to enhance business environment. More inflows of FIRE also implicitly imply that the business environment is now becoming more conducive. Although that study has several limitations, its finding provides a preliminary results which useful as reference for the time being. In addition, SSGAP is also observed as having high impact in lowering affordability level. Hence, focusing on increasing the supply of houses may help in improving the level of affordability.

\section{CONCLUSION}

This study aims at investigating the implication of inflows of FIRE into several developing countries. This research is of particular important especially when several countries, which received huge inflows of FDI in manufacturing sectors are no longer in that position. This is partly due to the emergence of new locations such as China, India, Vietnam and few others. The proponents of FDI in services (FDIS), including real estate markets tend to conclude that FDIS or FIRE could easily replace FDIM to continue developing host countries with a similar effect. This conclusion is too simplistic and without proper justification. Or, this statement could be drawn over an analysis focusing solely on income generation perspective. While this is still valid, the more proper analysis should also take into account its implication from cost perspective. This study attempts to fill in this gap by considering both perspectives into account. Hampered by limited information, this 
study managed to gather several countries, which have a breakdown statistics on FIRE. Many countries do not segregate the information on foreign capital flows into sectors, which disallowed us from utilising these countries as part of the samples.

Overall, this study found that FIRE tends to exert a positive consequence on host country's affordability in both models. Although FIRE exhibits affordabilityupgrading, to immediately rush to attract FIRE may not be wise idea. This is particularly true for two reasons. Firstly, apart from FIRE, supply gap and interest rates are also playing significant role in influencing the level of affordability. Secondly, referring to Masron and Fereidouni (2012) who found cointegration between FIRE and FDI, the inflows of FIRE could serve as additional factor to attract more inflows of FDI. At this point, what this study can suggest is for host countries to be more caution when dealing with foreign capital in the real estate market.

\section{ACKNOWLEDGEMENT}

The first author wishes to thank Universiti Sains Malaysia for funding this research under Research University (RU) Grant Scheme No. 1001/PMGT/816220.

\section{NOTES}

1. Generally, FDI is done due to the desire to have a control over the operations or to exploit fully some kind of production technology or managerial know-how (He et al., 2011).

2. Affordability can be on various items such as medical treatment, school attainment and so on. In this study, the focus is on house affordability. Another major issue is regarding the measurement of affordability. The use of aggregate information such as national affordability level may not be fully captured the true reality of affordability in that particular country especially when the country facing a serious variation of affordability level across states or cities (Jones, Watkins, \& Watkins, 2011). We put aside this issue as there will be another research to be conducted to solve this issue.

3. From the same table of Agnello and Schuknecht (2009), only Sweden and Netherlands are found to have boom period longer than burst period. In addition to UK, Italy is also demonstrated a similar persistence.

4. This point can be classified under cost of construction. English (2013), for instance, is among studies that stressed the importance of construction input prices. English (2013) argued that one of the critical factors contributing to the affordability problem in New Zealand is input cost of housing or building. Relative to its neighbouring country, Australia, the cost of building materials in New Zealand is obviously higher. 
Apart from cost of building materials, English (2013) also stated that the structure of infrastructure financing and the timing levies are to be paid, has partly explained the rising market price for housing.

5. In the case of developed countries, state support is mandatory in order to help these households to own a house.

6. We fully aware about the different meaning for deposit account and deposit for buying house but still believe that the two carry similar implication on house affordability. Higher savings or deposits mean higher affordability to pay the down payment to buy a house.

7. Time-fixed effect and combination of both (time and cross effects) models are also tested but country-fixed effect model found to be the best. Similar case is for random effect model. Although all are tested but country-random effect model is observed to be outperforming the rest.

\section{REFERENCES}

Agnello, L., \& Schuknecht, L. (2009). Booms and busts in housing markets: Determinants and implications. European Central Bank Working Paper Series No. 1071/July 209. Frankfurt, Germany: European Central Bank. Retrieved from http://www. ecb.europa.eu/pub/pdf/scpwps/ecbwp1071.pdf

André, C. (2010). A bird's eye view of OECD housing markets. OECD Economics Department Working Papers No. 746. Paris, France: OECD.

Bentzien, V., Rottke, N. \& Zietz, J. (2012). Affordability and Germany's low homeownership rate. International Journal of Housing Markets and Analysis, 5(3), 289-312. https://doi.org/10.1108/17538271211243616

Bernanke, B. (2009). Four questions about the financial crisis. Retrieved from http://www. federalreserve.gov/newsevents/speech/bernanke20090414a.htm.

Borio, C., \& McGuire, P. (2004). Twin peaks in equity and housing prices? BIS Quarterly Review, March, 79-93.

Bramley, G. (1994). An affordability crisis in British housing: Dimensions, causes and policy impact. Housing Studies, 9(1), 103-124. https://doi. org/10.1080/02673039408720777

Daly, K. (2010). Australian house prices affordability: An international comparison of the determinants of house price's performance, 1980-2009, 9 July. Available at SSRN: https://ssrn.com/abstract=1636633 or http://dx.doi.org/10.2139/ssrn.1636633

English, H. B. (2013). Introduction. In 9th Annual Demographia International Housing Affordability Survey: Ratings for Metropolitan Markets. New Zealand: Performance Urban Planning. Retrieved January 2014 from http://www. demographia.com/dhi2013.pdf

Errunza, V. (2001). Foreign portfolio equity investments, financial liberalization, and economic development. Review of International Economics, 9(4), 703-726. https://doi.org/10.1111/1467-9396.00308

European Central Bank. (2003). Structural factors in the EU housing markets. Frankfurt am Main: European Central Bank. 
Finicelli, A. (2007). House price developments and fundamentals in the United States. Occasional Paper No. 7. Italy: Bank of Italy.

Girouard, N., Kennedy, M., van de Noord, P., \& André, C. (2006). Recent house price developments: The role of fundamentals. OECD Working Paper No. 475. France, Paris: OECD.

Glindro, E. T., Subhanij, T., Szeto, J., \& Zhu, H. (2008). Determinants of house prices in nine Asia-Pacific economies. Bank of International Settlements (BIS) Working Paper Series No. 52. Switzerland: Bank of International Settlements, pp. 340-370.

He, C., Wang, J., \& Cheng, S. (2011). What attracts foreign direct investment in China's real estate development? Annals of Regional Science, 46(2), 267-293. https://doi. org/10.1007/s00168-009-0341-4

Holt, J. (2009). A summary of the primary causes of the housing bubble and the resulting credit crisis: A non-technical paper. The Journal of Business Enquiry, 8(1), 120129.

Jackson, J. R., \& Kaserman, D. L. (1980). Default risk on home mortgage loans: A test of competing hypothesis. Journal of Risk \& Insurance, 47(4), 678-690. https://doi. org/10.2307/252290

Jiang, D., Chen, J., \& Isaac, D. (1998). The effect of foreign investment on the real estate industry in China. Urban Studies, 35(11), 2101-2110. https://doi. org/10.1080/0042098984024

Jones, C., Watkins, C., \& Watkins, D. (2011). Measuring local affordability: Variations between housing market areas. International Journal of Housing Markets and Analysis, 4(4), 341-356. https://doi.org/10.1108/17538271111172148

Kim, K-.H., \& Cho, M. (2010): Structural changes, housing price dynamics and housing affordability in Korea. Housing Studies, 25(6), 839-856. https://doi.org/10.1080/ 02673037.2010 .511163

Klyuev, V. (2008). What goes up must come down? House price dynamics in the United States. IMF Working Paper Series No. WP/08/187. Washington: International Monetary Fund.

Masron, T. A., \& Fereidouni, H. G. (2012). Integration of FDI in real estate and FDI in manufacturing sector: Evidence from developing countries. Paper presented at The 14th Malaysian Finance Association Conference, 1-3 June, 2012, Penang, Malaysia, pp. 558-563.

Masron, T. A., \& Mohd Nor, A. H. S. (2016). Foreign investment in real estate and affordability in emerging markets. Jurnal Ekonomi Malaysia, 50(1), 15-28.

Mendoza, E., \& Terrones, M. E. (2008). An anatomy of credit booms: Evidence from macro aggregates and micro data. NBER Working Paper No. 14049. Cambridge, MA: The National Bureau of Economic Research.

Mihaljek, D. (2005). Free movement of capital, the real estate market and tourism: a blessing or a curse for Croatia on its way to the European Union? Retrieved from http://fes.hr/E-books/pdf/Croatian\%20accession\%20to\%20EU_3td/08_0.pdf

Minoiu, C., \& Reddy, S. G. (2009). Development aid and economic growth: A positive long-run relation. IMF Working Paper Series No. WP/09/118. Washington: International Monetary Fund. 
Organisation for Economic Co-operation and Development [OECD] (2004). Economic survey of the Netherlands. Paris: OECD Publishing.

OECD. (2005a). Economic survey of the United Kingdom. Paris: OECD Publishing.

OECD. (2005b). Economic survey of Korea. Paris: OECD Publishing.

OECD. (2006). Economic survey of Ireland. Paris: OECD Publishing.

OECD. (2010). OECD economic outlook (Vol. 2010/2). Paris: OECD Publishing.

OECD. (2011). Housing and the economy: Policies for renovation. Retrieved from http:// www.oecd.org/newsroom/46917384.pdf

Pattison, B., Diacon, D., \& Vine, J. (2010). Tenure trends in the UK housing system: Will the private rented sector continue to grow? Leicestershire: Building and Social Housing Foundation.

Sirmans, C. F., \& Worzala, E. (2003). International direct real estate investment: A review of the literature. Urban Studies, 40(5-6), 1081-1114. https://doi.org/10.1080/ 0042098032000074335

Stapledon, N. (2010). A history of housing prices in Australia 1880-2010. School of Economics Discussion Paper: 2010/18. Sydney, Australia: The University of New South Wales Australian School of Business.

Trimbath, S., \& Montoya, J. (2002). Housing affordability in three dimensions: Price, income and interest rates. Milken Institute Working Paper Series No. 21. Santa Monica, CA: Milken Institute.

United Nations Conference on Trade and Development [UNCTAD] (2013). UNCTAD stats. Retrieved January 2014 from http://www.unctadstat.unctad.org/EN/

Wood, G., \& Ong, R. (2011). Factors shaping the dynamics of housing affordability in Australia 2001-06. Housing Studies, 26(7-8), 1105-1127. https://doi.org/10.108 0/02673037.2011.615156

World Bank. (2013). World development indicators. Retrieved February 2014 from http:// data.worldbank.org/data-catalog/world-development-indicators

Wright, C., \& Hogue, R. (2012). Housing trends and affordability. Royal Bank of Canada (RBC) Economics, August 2012. Retrieved February 2014 from http://www.rbc. $\mathrm{com} /$ newsroom/_assets-custom/pdf/HA-0827-2012.pdf 